\title{
Mutation analysis underlying the downregulation of the thyroid hormone receptor $\beta$ I gene in the Chinese breast cancer population
}

This article was published in the following Dove Press journal:

OncoTargets and Therapy

16 October 2015

Number of times this article has been viewed

\author{
Yaqin Ling' \\ Xiaoling Ling ${ }^{2}$ \\ Lu Fan' \\ Yong Wang ${ }^{3, *}$ \\ Qing $\operatorname{Li}^{1}{ }^{1, *}$
}

'Department of Pathophysiology, College of Basic Medical, Lanzhou University, ${ }^{2}$ Medical Oncology, Lanzhou University First Hospital, ${ }^{3}$ Department of Gastroenterology, Lanzhou General Hospital of Lanzhou Military Command of PLA, Lanzhou, Gansu Province, People's Republic of China

*These authors contributed equally to this work
Purpose: There are a growing number of reports suggesting that the aberrant expression and mutation of the thyroid hormone receptor $\beta 1$ (TR $\beta 1)$ gene is associated with the development of human neoplasms. However, its exact role in the pathogenesis of breast cancer remains elusive. In the present study, we analyzed the mRNA expression and mutations of the $T R \beta 1$ gene in the Chinese breast cancer population.

Methods: The expression of $T R \beta 1$ mRNA was examined by real-time quantitative reverse transcription polymerase chain reaction, and mutations in the TR $\beta 1$ gene in the hotspot region that spans exons 7-10 were analyzed by polymerase chain reaction single-strand conformation polymorphism and automated DNA sequencing.

Results: TR $\beta 1$ mRNA expression was significantly reduced in all 105 breast cancer specimens examined. A total of 20 samples showed truncating mutations within the exons $7-10$ of the TR $\beta 1$ gene, where eight cases harbored a frame shift mutation (five cases of c.850insA in exon 7 and three cases c.1028delA in exon 8), whereas missense mutations were observed in 12 breast cancer cases. The 20 cases with mutation in the TR $\beta 1$ gene showed a reduction in TR $\beta 1$ mRNA expression compared with that observed in matched normal tissues. The mutation was also correlated with menopausal stage and estrogen receptor status.

Conclusion: The findings of the present study suggest that the aberrant expression and mutations of the $T R \beta 1$ gene are associated with the development of breast cancer and that the mutations in the TR $\beta 1$ gene partly serve as the underlying mechanism for TR $\beta 1$ inactivation in the Chinese breast cancer population.

Keywords: breast cancer, mutation, thyroid hormone receptor $\beta 1$, biomarker

\section{Introduction}

Breast cancer ranks as the second most prevalent cancer ${ }^{1}$ and one of the most common malignancies affecting women around the world with a mortality rate of more than one million per year. ${ }^{2}$ Numerous physiological agents and pathological conditions as well as environmental risk factors have been proposed to influence the development of this neoplasia. Among these, thyroid hormone (triiodothyronine, T3, and its precursor thyroxine, T4) has long been postulated since Beatson described the use of thyroid extracts for metastatic breast cancer treatment more than a century ago. ${ }^{3}$

Thyroid hormones control the development and maintenance of homeostasis of various organs in vertebrates. These cellular effects are mediated by the binding of T3 to thyroid hormone receptors (TRs), which are located within the nuclei of target cells. ${ }^{4}$ TRs are encoded by two genes, TR $\alpha$ and TR $\beta$, which are located on human chromosomes 17 and 3, respectively. By alternative splicing and differential promoter 
usage, these two genes have been determined to encode for nine polypeptides, of which four bind T3 and are functional receptors, namely, TR $\alpha 1, \mathrm{TR} \beta 1, \mathrm{TR} \beta 2$, and TR $\beta 3$. ${ }^{5}$ Several recent studies have strongly suggested that TR $\beta 1$ might be involved in the pathogenesis of human cancers. ${ }^{6-8}$ Nonetheless, studies on TR $\beta 1$ in human breast cancer are limited, and only a few have described the abnormal expression of TR $\beta 1$ in breast tumors and breast cancer cell lines. ${ }^{9,10}$ Our earlier study has shown that hypermethylation of the $T R \beta 1$ promoter frequently occurred in breast tumors, and an inverse relationship exists between $T R \beta 1$ promoter methylation and $T R \beta 1$ mRNA expression. ${ }^{11}$ However, promoter methylation could not explain all cases that lost expression of $T R \beta 1 \mathrm{mRNA}$ and it only partially contributed to the loss of $T R \beta 1$ expression.

Inactivation of the TR $\beta 1$ gene in breast cancer might be related to other mechanisms. Several reports have indicated a close association between somatic mutations of $T R \beta 1$ and human cancers. ${ }^{12-14}$ On the basis of these observations, we wanted to determine the involvement of TR $\beta 1$ mutations in the pathogenesis of breast cancer in the Chinese population and its contributory role in the loss of TR $\beta 1$ expression. Therefore, we screened for $T R \beta 1$ mutations within exons 7-10, which have been reported to be hotspots for renal cancer, ${ }^{15}$ as well as analyzed its relationship with the mRNA expression of $T R \beta 1$.

\section{Materials and methods Biological specimens}

Tumor and corresponding nontumor tissues not infiltrated by tumors and confirmed by a pathologist were collected from 105 breast cancer patients who underwent breast resection at the Gansu Province People Hospital, Lanzhou General Hospital and Lanzhou University First Hospital from 2006 to 2013. The patients were excluded with thyroid diseases or abnormal thyroid status testing. The patients were female within the age range of 32-65 years (median, 48 years).
Breast cancers were classified according to the tumor-nodemetastasis scheme and differentiation stage. The surgical specimens obtained from these patients were immediately frozen in liquid nitrogen and stored at $-70^{\circ} \mathrm{C}$ for analysis. All samples were obtained with informed consent, and the ethical committees of the Gansu Province People Hospital, Lanzhou General Hospital, and Lanzhou University First Hospital authorized the study.

\section{Real-time quantitative RT-PCR analysis of $T R \beta I$ expression}

Total RNA from tissues was extracted using Trizol solution. Reverse transcription (RT) was performed in a $20 \mu \mathrm{L}$ reaction system according to the manufacturer's recommendation. To analyze $T R \beta 1 \mathrm{mRNA}$ expression, real-time quantitative RTpolymerase chain reaction (RT-PCR) was performed. Briefly, RT-PCR amplification was carried out for each sample in a $12.5 \mu \mathrm{L}$ final reaction mixture containing $1 \mu \mathrm{L}$ of cDNA, $3 \mathrm{nM}$ TaqMan probe, $5.5 \mathrm{mM} \mathrm{MgCl}_{2}, 10 \mathrm{nM}$ of each primer, $0.6 \mathrm{U}$ of Platinum Taq polymerase, and $200 \mu \mathrm{M}$ of deoxyguanosine triphosphate. After an initial denaturation step at $95^{\circ} \mathrm{C}$ for 1.5 minutes, 40 cycles of 15 seconds at $95^{\circ} \mathrm{C}$ and 56 seconds at $60^{\circ} \mathrm{C}$ for annealing and extension were run on an iQ5 PCR machine (Bio-Rad Laboratories, Hercules, CA, USA).

TR $\beta 1$ mRNA levels were normalized to $\beta$-actin. The primer sequences used in the present study are presented in Table 1. All reactions were performed in duplicate. The relative expression of $T R \beta 1$ was analyzed by the comparative $\mathrm{Ct}$ method. Thermal dissociation plots were examined for biphasic melting curves.

\section{PCR-single-strand conformation polymorphism (SSCP) analysis}

DNA was extracted from tumor and corresponding nontumor tissue samples using standard methods. The primers

Table I Primer and probe sequences used in this study

\begin{tabular}{|c|c|c|c|}
\hline & Forward primer sequence $\left(5^{\prime} \rightarrow 3^{\prime}\right)$ & Probe sequence $\left(5^{\prime} \rightarrow 3^{\prime}\right)^{*}$ & Reverse primer sequence $\left(5^{\prime} \rightarrow 3^{\prime}\right)$ \\
\hline \multicolumn{4}{|c|}{ Real-time RT-PCR } \\
\hline \multirow[t]{2}{*}{$\operatorname{TR} \beta I$} & CCAGAAGACATTGGACAAGCA & FAM-ATCATCACACCAGCAA & GCAGCTCACAAAACATAGGCA \\
\hline & & TTACCAGAGTGGTGT-AMRA & \\
\hline \multirow[t]{2}{*}{$\beta$-actin } & GCTCGTCGTCGACAACGGCTC & FAM-TGGCGGCACCACCAT & CAAACATGATCTGGGTCATCTTCTC \\
\hline & & GTACC-AMRA & \\
\hline \multicolumn{4}{|c|}{ PCR-SSCP $(T R \beta I)$} \\
\hline Exon 7 & GCATCTGTGTGCCTTGTCTC & & TGAGGTAGAAAACACTGGCATA \\
\hline Exon 8 & СААСТTСТTСАТTTAААТСТTТСТTTТ & & ATTCCTGGAAACTGATGAAACTAT \\
\hline Exon 9 & TGTTGTTCCTGACTGGCATT & & AGCGCTAGACAAGCAAAAGC \\
\hline Exon 10 & TAAAGGCCTGGAATTGGACA & & GGCAATGGAATGAAATGACA \\
\hline
\end{tabular}

Note: *There is no probe sequence in SSCP for exons 7-10.

Abbreviations: PCR-SSCP, polymerase chain reaction-single strand conformation polymorphism; RT-PCR, reverse transcription polymerase chain reaction; SSCP, single strand conformation polymorphism; TR $\beta$ I, thyroid hormone receptor $\beta I$. 
used in this analysis are summarized in Table 1. PCR was performed for 35 cycles with the appropriate annealing temperatures. The bands were excised from agarose gels and purified with GFX Amersham Kit (Qiagen, Valencia, CA, USA), following the manufacturer's protocol. After PCR analysis, the reaction mixture was mixed with an equal amount of $95 \%$ formamide containing bromophenol blue and $20 \mathrm{mM}$ EDTA, then incubated at $94^{\circ} \mathrm{C}$ for 7 minutes and electrophoresed on a Gene-Phor system (BioRad Laboratories) at $15^{\circ} \mathrm{C}$. The gels were stained using a silver staining method, and bands were visualized and photographed. Samples that showed band-shifts different from the wild-type bands were identified as mutants and submitted for sequencing.

\section{Automated sequencing}

The samples that showed variant band-shifts in single-strand conformation polymorphism (SSCP) were reamplified for sequencing. DNA sequencing was performed using an automated sequencer ABI PRISM 310 (Thermo Fisher Scientific, Waltham, MA, USA). The process of sequencing was conducted twice to stringently confirm and classify the mutations.

\section{Statistical analysis}

Statistical analysis was performed using the SPSS 10.0 software (SPSS Inc., Chicago, IL, USA). The data are expressed as the mean \pm SD. The values of mRNA expression level were analyzed by independent samples $t$-test or pairedsamples $t$-test. The chi-square test was utilized to analyze the relationship between $T R \beta 1$ mutations and pathology parameters. $P$-values less than 0.05 were designated as statistically significant.

\section{Results}

\section{$T R \beta I$ mRNA expression is frequently downregulated in Chinese breast cancer patients}

We analyzed the mRNA expression of $T R \beta 1$ in 105 pairs of breast cancer specimens and matched normal tissues by real-time quantitative RT-PCR. The mRNA expression level of $T R \beta 1$ was reduced in 84 of the $105(80 \%)$ breast cancer tissue samples compared with the matched normal tissues. The mean mRNA expression level of the breast cancer tissue samples was 3.08 \pm 4.06 , compared with $12.84 \pm 11.6$ in matched normal tissues. Statistical analysis showed that $T R \beta 1$ mRNA expression was significantly reduced in breast cancer tissues $(P=0.02)$.

\section{Mutational analysis of the $T R \beta I$ gene of Chinese breast cancer patients}

Changes or shifts in electrophoretic mobility of single-strand DNA bands of exons 7-10 of the $T R \beta 1$ were analyzed relative to that of the wild-type, which has been deposited in Genebank and its GeneID is 7068. Samples that showed alterations were identified as SSCP-positive and were then sequenced to confirm and classify the detected mutation. The mutations found were exclusively associated with the breast tumor samples and were not present in the normal adjacent tissue samples. A total of 20 samples (19.04\%) showed truncating mutations in the exons $7-10$ of the $T R \beta 1$ gene, as listed in Table 2. Among these, eight cases harbored frame shift mutations (five cases of c.850insA in exon 7 and three cases of c.1028delA in exon 8), and the remaining were missense mutations that were observed in 12 cases of breast cancer (Figure 1; Table 2). Interestingly, mutations were identified in exons 7-9. However, no mutation was identified in exon 10 .

To evaluate the possible pathogenicity of the observed changes, we analyzed the relationship between $T R \beta 1$ gene mutation and the clinicopathological characteristics of the tumor specimens (Table 3). Highly significant associations between the mutation profile of $T R \beta 1$ and menopausal stage and estrogen receptor (ER) status were observed. On the other hand, no association between the mutation profile of the $T R \beta 1$ gene and other clinicopathological characteristics such as tumor stage were detected $(P>0.05)$.

\section{Relationship between $T R \beta I$ mutations and TR $\beta I$ mRNA expression profiles in Chinese breast cancer patients}

A strong correlation between mutations and mRNA expression levels of $T R \beta 1$ of the 20 Chinese breast cancer patients was observed. The mean mRNA expression level of the 20 breast cancer tissues samples that harbored mutations was $2.98 \pm 4.12$, compared with $13.44 \pm 10.6$ in the matched normal tissues. The difference of gene mutation and mRNA expression was statistically significant $(P<0.05)$.

Table 2 TR $\beta$ I gene mutation(s) in breast cancer

\begin{tabular}{lllll}
\hline Exon & $\begin{array}{l}\text { Nucleotide } \\
\text { change }\end{array}$ & $\begin{array}{l}\text { Effect on } \\
\text { protein }\end{array}$ & Mutation effect & $\begin{array}{l}\text { Number } \\
\text { of cases }\end{array}$ \\
\hline 7 & c.850insA & NA & Frame shift & 5 \\
8 & c. I024C $>$ G & Pro247Ala & Missense mutation & 4 \\
8 & c. 1028delA & NA & Frame shift & 3 \\
9 & c. II88G $>$ A & Glu324Lys & Missense mutation & 3 \\
9 & c. $1336 G>$ C & Lys35IAsp & Missense mutation & 5 \\
\hline
\end{tabular}

Abbreviations: NA, not applicable; TR $\beta$ I, thyroid hormone receptor $\beta \mathrm{I}$. 
A

mut

c.850insA

GC CAA GAAG GA A GC T G

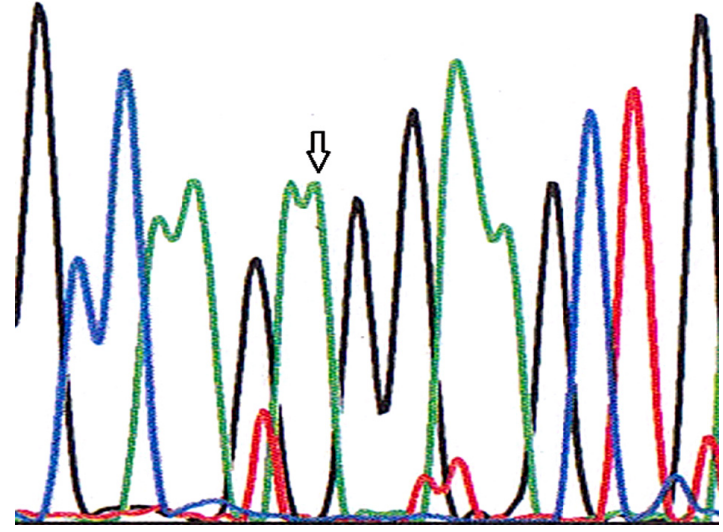

C

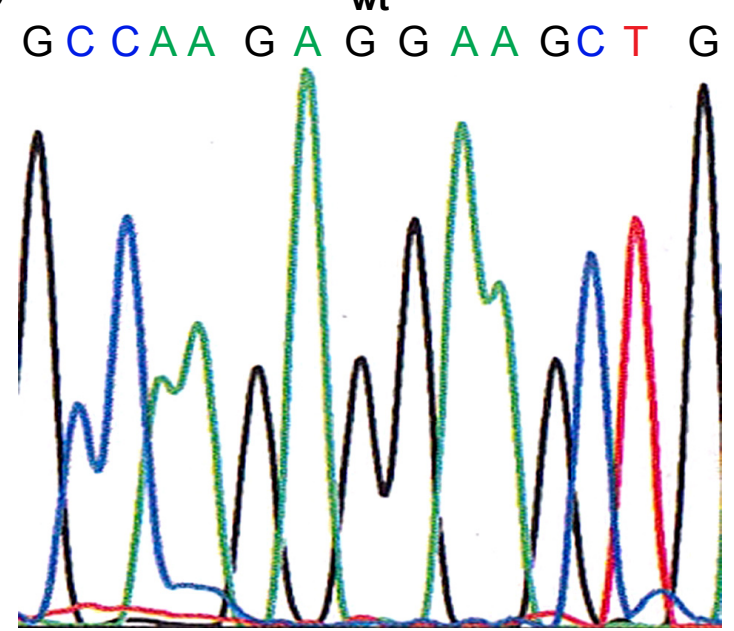

B

mut

c.1028delA

$T T G$ GAC A GCACCAA T A

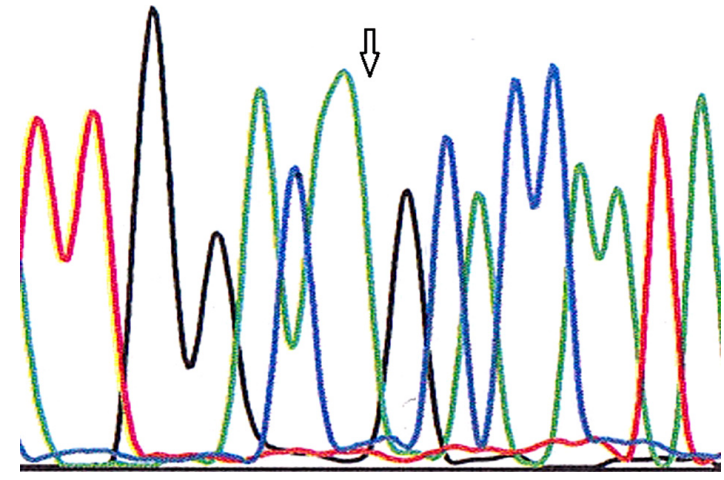

D
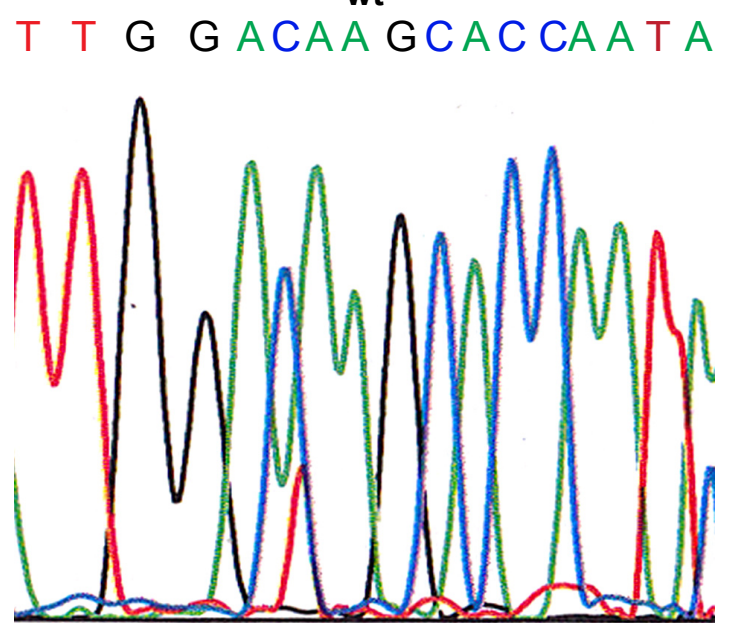

Figure I Sequencing chromatograms show two mutations in TR $\beta$ I gene (c.850insA in exon 7 and c. 1028delA in exon 8, marked by arrows) and corresponding wild-type sequences.

Notes: (A) Mutant type of exon 7, (B) mutant type of exon 8, (C) wild type of exon 7, (D) wild type of exon 8.

Abbreviations: mut, mutant type; TR $\beta I$, thyroid hormone receptor $\beta I$; wt, wild type.

Table 3 Correlation between mutation of TR $\beta I$ and clinicopathological features of breast cancer patients

\begin{tabular}{lllll}
\hline $\begin{array}{l}\text { Clinicopathological } \\
\text { features }\end{array}$ & $\begin{array}{l}\text { Patients } \\
\text { (n) }\end{array}$ & $\begin{array}{l}\text { Mutation, } \\
\text { n (\%) }\end{array}$ & $\chi^{2}$ & P-value \\
\hline $\begin{array}{l}\text { Age (years) } \\
\quad>50\end{array}$ & 49 & $7(14.28 \%)$ & $1.35 \mathrm{I}$ & 0.245 \\
$\quad 550$ & 56 & $13(23.21 \%)$ & & \\
$\begin{array}{l}\text { Tumor stage } \\
\quad \text { Stage II }\end{array}$ & 45 & $13(28.89 \%)$ & 0.623 & 0.430 \\
$\quad$ Stage III, stage IV & 60 & $7(11.67 \%)$ & & \\
Menopausal status & & & & \\
$\quad \begin{array}{l}\text { Pre } \\
\quad \text { Post }\end{array}$ & 46 & $15(32.61 \%)$ & 9.764 & 0.002 \\
ER status & 59 & $5(8.474 \%)$ & & \\
$\quad$ Positive & & & & \\
$\quad$ Negative & 62 & $4(9.52 \%)$ & 4.118 & 0.042 \\
\hline
\end{tabular}

Abbreviations: ER, estrogen receptor; TR $\beta$ I, thyroid hormone receptor $\beta$ I.

\section{Discussion}

There is an increasing research evidence that the aberrant expression and mutation of the TR $\beta 1$ gene could be associated with the development of human neoplasms. ${ }^{12,13,16-19}$ Transgenic mice $\left(\mathrm{TR} \beta^{\mathrm{PV} / \mathrm{PV}}\right)$ harboring a PV mutation that was originally identified in a patient with thyroid hormone resistance spontaneously developed thyroid cancer. ${ }^{20} \mathrm{How}-$ ever, information on whether TR $\beta 1$ mutations are associated with breast cancer is limited. Only two reports described a totally different situation regarding $T R \beta 1$ gene mutations. Silva et al reported the presence of truncated $T R \beta 1$ mRNA in 6 of 70 sporadic breast cancer patients $(9 \%),{ }^{21}$ and Li et al described the absence of mutations in the TR $\beta 1$ gene in sporadic breast cancers. ${ }^{22}$ The present study aimed to clarify this controversy and to establish whether $T R \beta 1$ gene 
mutations contribute to breast carcinoma development/ progression in the Chinese population.

The present study screened for mutations in the TR $\beta 1$ gene that spans exons $7-10$ that were previously reported as hotspots in renal cancer. ${ }^{15} T R \beta 1$ gene mutations were identified in 20 out of 105 patients. Five cases harbored frame shift mutations in exon 7, three cases showed frame shift mutations in exon 8 , and the remaining were missense mutations. In one study, point mutations in TR $\beta 1$ cDNA that were detected using the mismatch RNase cleavage assay were observed in $76 \%$ (13/17 tumors) of human hepatocellular carcinomas. ${ }^{12}$ Puzianowska-Kuznick et a ${ }^{13}$ reported that mutations in the $T R \beta 1$ cDNA were detected in $93.75 \%$ of papillary thyroid carcinomas. Kamiya et al ${ }^{15}$ demonstrated that approximately $30 \%$ (7 of 22) of TR $\beta 1$ cDNA was mutated in human renal clear cell carcinomas and that most of the mutations were localized within the hormone-binding domain. Comparison of the mutation sites showed that the mutations detected in the present study were novel. However, the loss-of-function mutation in the TR $\beta 1$ gene detected in the present study was similar to that described in a previous study, wherein a loss of the hormone-binding and transcriptional activity and the development of dominant-negative activity were observed. In addition, the loss-of-function mutation in the TR $\beta 1$ gene might also affect the protein-protein interactions in the network of cellular proto-oncogenes and tumor suppressors. For example, TR $\beta 1$ was shown to physically associate with the tumor suppressor protein $\mathrm{p} 53 .^{23,24} \mathrm{TRs}$ also stimulate the expression of the c-fos and c-jun proto-oncogenes, increase expression of the c-Fos and c-Jun proteins, and activate AP1 transcriptional activity via a T3-independent pathway. ${ }^{25-27}$

We also analyzed the relationship between TR $\beta 1$ mutations and clinical pathological features. Li et $\mathrm{al}^{22}$ reported that although no significant correlation between alterations in TR $\beta 1$ expression and any clinical feature was observed, an association between alterations in expression and early onset cancer (patients with ages $<50$ years) was detected. In the present study, a significant association between TR $\beta 1$ mutations and menopausal and ER status was observed. The majority of the mutations in the TR $\beta 1$ gene were detected in premenopausal patients $(15 / 20,32.61 \%)$. We also found a significant association between $T R \beta 1$ mutations and ER status, where the majority of mutations $(16 / 20,25.39 \%)$ were observed in ER-negative patients. These findings suggest that breast cancer patients harboring $T R \beta 1$ mutations are likely to follow a more aggressive course and generate a worse prognosis.

Our earlier study discovered that $T R \beta 1$ promoter hypermethylation frequently occurred in breast tumor tissues, and that there was an inverse relationship between $T R \beta 1$ promoter methylation and mRNA expression. ${ }^{11}$ However, promoter methylation could not explain all cases that lost the expression of TR $\beta 1$ mRNA, thus indicating that this post-translational activity only partially contributed to the loss of TR $\beta 1$ expression. The present study demonstrated that mutation in the $T R \beta 1$ gene also contributed to mRNA expression. The 20 cases with mutation in the TR $\beta 1$ gene showed reduced expression of $T R \beta 1$ mRNA compared with that in matched normal tissues. Interestingly, three cases without TR $\beta 1$ promoter methylation but showing reduced expression in our previous study were determined to harbor a specific mutation in which an A nucleotide was deleted in exon 8 . This observation suggests that $T R \beta 1$ mutations in breast cancer partially contributed to the loss of $T R \beta 1$ expression. Compared with our previous study, we also discovered that 13 cancer cases harbored both mutation and promoter hypermethylation that might have led to the complete inactivation of TR $\beta 1$. According to Knudson's proposed two-hit hypothesis, disruption of both copies of a given gene is required for the complete loss of function of a tumor suppressor gene. ${ }^{28}$ Our findings correlate with Knudson's model. Abnormal methylation of the promoters of tumor suppressor genes has been established as the second hit, with intragenic mutations being the first hit. ${ }^{29}$

\section{Conclusion}

To our knowledge, this is the first investigation involving mutation screening of the TR $\beta 1$ gene that resulted in a decrease in TR $\beta 1$ mRNA expression in Chinese breast cancer cases. This finding suggests that mutations in the $T R \beta 1$ gene might be the underlying mechanism for $T R \beta 1$ partial inactivation and thus may be used as a prognostic biomarker. However, our study was conducted on a limited number of cases. Therefore, further large-scale progressive studies on different exons and introns are required to establish the definitive role of TR $\beta 1$ in the pathogenesis of breast cancer.

\section{Acknowledgments}

This present study has been supported by the Pedestal Project of Gansu Provincial Science (090NKCA126), the Medical Research Fund of PLA (CLZ 11JB05), and the International Scientific and Technological Cooperation Project in Gansu Province (1011WCGA166).

\section{Disclosure}

The authors report no conflicts of interest in this work. 


\section{References}

1. Ferlay J, Shin HR, Bray F, Forman D, Mathers C, Parkin DM. Estimates of worldwide burden of cancer in 2008: GLOBOCAN 2008. Int J Cancer. 2010;127(12):2893-2917.

2. Coughlin SS, Ekwueme DU. Breast cancer as a global health concern. Cancer Epidemiol. 2009;33(5):315-318.

3. Beatson GT. On the treatment of inoperable cancer of the mamma: suggestions for a new method of treatment with illustrative cases. Lancet. 1986;2:104-165.

4. Cheng SY. New insights into the structure and function of the thyroid hormone receptor. J Biomed Sci. 1995;2(2):77-89.

5. Martinez MB, Ruan M, Fitzpatrick LA. Altered response to thyroid hormones by prostate and breast cancer cells. Cancer Chemother Pharmacol. 2000;45(2):93-102.

6. Garc1'a-Silva S, Aranda A. The thyroid hormone receptor is suppressor of ras-mediated transcription, proliferation, and transformation. Mol Cell Biol. 2004;24(1):7514-7523.

7. Oetting A, Yen PM. New insights into thyroid hormone action. Best Pract Res Clin Endocrinol Metab. 2007;21(2):193-208.

8. Hsieh ML, Juang HH. Cell growth effects of triiodothyronine and expression of thyroid hormone receptor in prostate carcinoma cell. J Androl. 2005;26(3):422-428.

9. Burke RE, McGuire WL. Nuclear thyroid hormone receptors in a human breast cancer cell line. Cancer Res. 1978;38(11):3769-3773.

10. Li Z, Alboladejo V, Joly-Pharaboz MO, Nicolas B, Andre J. Antiestrogens prevent the stimulatory effects of 1-triiodothyronine on cell proliferation. Endocrinology. 1992;130(3):1145-1152.

11. Yaqin L, Xiaoying X, Jie H, et al. Aberrant methylation of the THRB gene in tissue and plasma of breast cancer patients. Cancer Genet Cytogenet. 2010;196(2):140-145.

12. Lin KH, Shieh HY, Chen SL, Hsu HC. Expression of mutant thyroid hormone nuclear receptors in human hepatocellular carcinoma cells. Mol Carcinog. 1999;26(1):53-61.

13. Puzianowska-Kuznick M, Krystyniak A, Madej A, Cheng SY, Nauman J. Functionally impaired TR mutants are present in thyroid papillary cancer. J Clin Endocrinol Metab. 2002;87(3):1120-1128.

14. Puzianowska-Kuznicka M, Nauman A, Madej A, Tanski Z, Cheng S, Nauman J. Expression of thyroid hormone receptors is disturbed in human renal clear cell carcinoma. Cancer Lett. 2000;155(2):145-152.

15. Kamiya Y, Puzianowska-Kuznicka M, McPhie P, Nauman J, Cheng SY, Nauman A. Expression of mutant thyroid hormone nuclear receptors is associated with human renal clear cell carcinoma. Carcinogenesis. 2002;23(1):25-33.

16. Dobrovic A, Houle B, Belouchi A, Bradley WE. erbA related sequence coding for DNA-binding hormone receptor localized to chromosome 3p21-3p25 and deleted in small cell lung carcinoma. Cancer Res. 1988;48(3):682-685.
17. Sisley K, Curtis D, Rennie IG, Rees RC. Loss of heterozygosity of the thyroid hormone receptor B in posterior uveal melanoma. Melanoma Res. 1993;3(6):457-461.

18. Ando S, Sarlis NJ, Oldfield EH, Yen PM. Somatic mutation of TRbeta can cause a defect in negative regulation of TSH in a TSHsecreting pituitary tumor. $J$ Clin Endocrinol Metab. 2001;86(11): 5572-5576.

19. Rosen MD, Privalsky ML. Thyroid hormone receptor mutations found in renal clear cell carcinomas alter corepressor release and reveal helix 12 as key determinant of corepressor specificity. Mol Endocrinol. 2009;23(8):1183-1192.

20. Suzuki H, Willingham MC, Cheng SY. Mice with a mutation in the thyroid hormone receptor beta gene spontaneously develop thyroid carcinoma: a mouse model of thyroid carcinogenesis. Thyroid. 2002; 12(11):963-969.

21. Silva JM, Dominguez G, Gonzalez-Sancho JM, et al. Expression of thyroid hormone receptor/erbA genes is altered in human breast cancer. Oncogene. 2002;21(27):4307-4316.

22. Li Z, Meng ZH, Chandrasekaran R, et al. Biallelic inactivation of the thyroid hormone receptor beta 1 gene in early stage breast cancer. Cancer Res. 2002;62(7):1939-1943.

23. Yap N, Yu CL, Cheng SY. Modulation of the transcriptional activity of thyroid hormone receptors by the tumor suppressor p53. Proc Natl Acad Sci U S A. 1996;93(9):4273-4277.

24. Bhat MK, Yu CI, Yap N, et al. Tumor suppressor p53 is a negative regulator in thyroid hormone receptor pathways. $J$ Biol Chem. 1997;272(46):28989-28993.

25. Lopez G, Schaufele F, Webb P, Holloway JM, Baxter JD, Kushner PJ. Positive and negative modulation of Jun action by thyroid hormone receptor at a unique AP1 site. Mol Cell Biol. 1993;13(5):3042-3049.

26. Perez P, Schonthal A, Aranda A. Repression of c-fos gene by thyroid hormone and retinoic acid receptors. J Biol Chem. 1993;268(31): 23538-23543.

27. Zhang XK, Wills KN, Husmann M, Hermann T, Pfahl M. Novel pathway for thyroid hormone receptor action through interaction with jun and fos oncogene activities. Mol Cell Biol. 1991;11(12): 6016-6025.

28. Knudson AG Jr, Hethcote HW, Brown BW. Mutation and childhood cancer: a probabilistic model for the incidence of retinoblastoma. Proc Natl Acad Sci U S A. 1975;72(12):5116-5120.

29. Jones PA, Laird PW. Cancer epigenetics comes of age. Nat Genet. 1999;21(2):163-167.
OncoTargets and Therapy

\section{Publish your work in this journal}

OncoTargets and Therapy is an international, peer-reviewed, open access journal focusing on the pathological basis of all cancers, potential targets for therapy and treatment protocols employed to improve the management of cancer patients. The journal also focuses on the impact of management programs and new therapeutic agents and protocols on

\section{Dovepress}

patient perspectives such as quality of life, adherence and satisfaction The manuscript management system is completely online and includes a very quick and fair peer-review system, which is all easy to use. Visit http://www.dovepress.com/testimonials.php to read real quotes from published authors. 